\title{
Osteoporosis after Stroke: A Review of the Causes and Potential Treatments
}

\author{
Stefano Carda ${ }^{a}$ Carlo Cisari ${ }^{b}$ Marco Invernizzi ${ }^{b}$ Maurizio Bevilacqua ${ }^{c}$ \\ a Department of Clinical and Experimental Medicine and ${ }^{\mathrm{b}}$ Division of Physical and Rehabilitative Medicine, \\ University of Eastern Piedmont A. Avogadro, Novara, and ' ${ }^{C}$ Endocrinology and Diabetes Unit, Department of \\ Medicine, Luigi Sacco Hospital (Vialba), University of Milan, Milan, Italy
}

\section{Key Words}

Bone mineral density $\cdot$ Osteoporosis $\cdot$ Stroke $\cdot$ Hemiplegia

\begin{abstract}
Osteoporosis is a known consequence of stroke, associated with an increased incidence of fractures, mainly of the hip, leading to further disability. The pattern of bone loss seen in stroke patients is different from that usually encountered with postmenopausal osteoporosis, since it is limited to the paretic side and more evident in the upper extremities. Several factors appear to have an influence on bone mass in stroke patients, such as the degree of paresis, gait disability and the duration of immobilization. The pathogenesis of osteoporosis after stroke remains unclear. Paresis, reduced mobility and reduced bone load seem to play a major role. Other factors such as nutritional and iatrogenic ones may also play an important part. In this paper, the clinical evidence, pathophysiology and possible treatments of poststroke osteoporosis will be reviewed.
\end{abstract}

Copyright $\odot 2009$ S. Karger AG, Basel

\section{Introduction}

Loss of bone mineral density (BMD) and osteoporotic fractures, particularly of the hip, are common complications after stroke.

\section{KARGER}

Fax +4161306 1234 E-Mail karger@karger.ch www.karger.com
(C) 2009 S. Karger AG, Basel

$1015-9770 / 09 / 0282-0191 \$ 26.00 / 0$

Accessible online at:

www.karger.com/ced
Osteoporosis after stroke differs from age-related osteoporosis or bone loss secondary to endocrine diseases, nutritional disorders and drug-related factors, since it is more evident on the paretic side and involving the upper extremities usually more than the lower [1-6].

The clinical significance of osteoporosis after stroke is that it results in skeletal fragility and in an increased risk of fractures, mainly of the hip $[7,8]$. Fractures are usually the triggering event that focuses attention on bone health of stroke survivors.

Complications from fractures lead to increased morbidity and mortality [9], but also to increased health care costs that they generate. Altogether, in stroke patients, hip fracture can be a clinical disaster, frequently leading to further disability [9].

In this paper, the clinical evidence, pathophysiology and possible treatments of poststroke osteoporosis will be reviewed.

\section{Clinical Evidence}

Stroke and Bone Loss

Stroke is frequently followed by extensive bone loss, precipitating the increased fracture risk in survivors. While bone loss has been recognized as a possible complication of hemiplegia since the sixties [10,11], it is only during the last two decades that several studies demon-

E-Mail stefano.carda@virgilio.it 
Table 1. Longitudinal studies on poststroke osteoporosis

\begin{tabular}{|c|c|c|c|c|}
\hline Authors & Subjects & $\begin{array}{l}\text { Site of DXA } \\
\text { measurement }\end{array}$ & $\begin{array}{l}\text { Time from stroke } \\
\text { to last measurement }\end{array}$ & Paretic/nonparetic difference \\
\hline $\begin{array}{l}\text { Lazoura } \\
\text { et al. }[15]\end{array}$ & $\begin{array}{l}43 \text { men, } \\
24 \text { women }\end{array}$ & $\begin{array}{l}\text { Fem. neck, troch., } \\
\text { prox. rad., UD rad. }\end{array}$ & 12 months & $\begin{array}{l}\text { Fem. neck }-13 \% \text {, troch. }-12.6 \% \text { ( } 12 \text { months }) \text {, } \\
\text { prox. rad., UD rad. }-7.34 \% \text { ( } 12 \text { months })\end{array}$ \\
\hline $\begin{array}{l}\text { Hamdy } \\
\text { et al. [3] }\end{array}$ & 16 at start & Total arm, total leg & 6 months & $\begin{array}{l}\text { 6-month BMC: total arm }-7.1 \%^{*} \text {, } \\
\text { total leg }-3.6 \% \%^{*}\end{array}$ \\
\hline $\begin{array}{l}\text { Ramnemark } \\
\text { et al. [31] }\end{array}$ & $\begin{array}{l}13 \text { men, } \\
11 \text { women }\end{array}$ & $\begin{array}{l}\text { Total body, total arm, } \\
\text { total leg }\end{array}$ & 12 months & $\begin{array}{l}\text { 12-month BMC: total arm }-22.9 \%^{*} \text {, } \\
\text { total leg }-6.8 \%^{*}\end{array}$ \\
\hline $\begin{array}{l}\text { Ramnemark } \\
\text { et al. [17] }\end{array}$ & $\begin{array}{l}13 \text { men, } \\
11 \text { women }\end{array}$ & $\begin{array}{l}\text { Total arm, humerus, } \\
\text { UD rad., } \\
\text { total femur, prox. femur }\end{array}$ & 12 months & $\begin{array}{l}12 \text { months: total arm }-15.2 \%^{*} \text {, } \\
\text { humerus }-11.6 \%^{*} \text {, UD rad. }-15.8 \%^{*} \text {, } \\
\text { total femur }-5 \%^{*} \text {, prox. femur }-7.4 \%^{*}\end{array}$ \\
\hline Liu et al. [33] & $\begin{array}{l}69 \text { men, } \\
35 \text { women }\end{array}$ & $\begin{array}{l}\text { Total rad., humerus, UL, } \\
\text { total femur, calcaneus, LL }\end{array}$ & 203 days & $\begin{array}{l}203 \text { days: total rad. }-3.9 \%^{*} \text {, } \\
\text { humerus }-10.4 \%^{*}, \mathrm{UL}-7.5 \%^{*} \text {, } \\
\text { total femur }-5.8 \%^{*} \text {, calcaneus }-1.2 \%^{*}, \mathrm{LL}-2.4 \%^{*}\end{array}$ \\
\hline $\begin{array}{l}\text { Jørgensen } \\
\text { et al. [14] }\end{array}$ & $\begin{array}{l}21 \text { men, } \\
19 \text { women }\end{array}$ & Fem. neck, troch. & 12 months & 12 months: fem. neck $-4 \%^{*}$, troch. $-4 \%^{*}$ \\
\hline $\begin{array}{l}\text { Jørgensen } \\
\text { et al. [13] }\end{array}$ & $\begin{array}{l}21 \text { men, } \\
19 \text { women }\end{array}$ & Fem. neck & 12 months & 12 months: fem. neck $-8 \% *$ \\
\hline $\begin{array}{l}\text { Jørgensen } \\
\text { et al. [30] }\end{array}$ & $\begin{array}{l}18 \text { men, } \\
10 \text { women }\end{array}$ & $\begin{array}{l}\text { Prox. humerus, } \\
\text { head, spine }\end{array}$ & 12 months & 12 months: prox. humerus $-12 \% *$ \\
\hline $\begin{array}{l}\text { Jørgensen } \\
\text { et al. [29] }\end{array}$ & $\begin{array}{l}18 \text { men, } \\
10 \text { women }\end{array}$ & Total leg & 12 months & 12 months: total leg $-5 \% *$ \\
\hline $\begin{array}{l}\text { Yavuzer } \\
\text { et al. [19] }\end{array}$ & $\begin{array}{l}19 \text { men, } \\
13 \text { women }\end{array}$ & $\begin{array}{l}\text { Lumbar spine, } \\
\text { fem. neck, UD rad. }\end{array}$ & 63-161 days & 161 days: fem. neck $-5 \%^{*}$, UD rad. $-12 \%^{*}$ \\
\hline
\end{tabular}

DXA = Dual-energy X-ray absorptiometry; fem. = femoral; troch. = trochanter; prox. = proximal; rad. = radius; UD = ultradistal; $\mathrm{UL}=$ upper limb; LL = lower limb; BMC = bone mineral content. ${ }^{*}=$ Difference found statistically significant by authors.

strated a significant reduction in BMD and bone mass following stroke [2, 12-19].

Bone loss starts in the days immediately following vascular brain injury and progressively accrues until the 3 rd-4th month after stroke $[3,6]$. Bone loss then progresses at lower speed almost until the end of the first year after stroke $[17,20]$.

After that, similarly to what has been reported in spinal cord injuries [21], a steady state is probably reached, leading to a condition of permanent bone loss [22] and a subsequent elevated fracture risk.

At the present time, a long-term course of bone loss after stroke has not been evaluated yet.

Some data on chronic stroke survivors (until 15 years after the lesion) are available, but only from cross-sectional studies [1, 2, 4, 6, 16, 20, 22-28].
Longitudinal studies are fundamental to understand changes in BMD and bone mass modifications after stroke. Unfortunately, no studies with a follow-up longer than 12 months are available [13-15, 17, 29-31] (table 1). Other studies evaluated bone loss in a shorter period of time $[3,19,32,33]$, while a longer follow-up is available in a single-subject study only [34].

Evidence suggests that bone loss typically takes place on the paretic side. During the first year after stroke, patients can lose up to $14 \% \mathrm{BMD}$ at the proximal femur [13, $15]$ and up to $17 \%$ at the upper extremities [15, 31, 35]. Bone loss can be observed at the proximal nonparetic femur, while at the nonparetic upper extremity BMD can increase [31].

In long-standing stroke patients (until 484 weeks after stroke), bone mineral content has been reported to de- 
crease as much as $21 \%$ for the upper limbs and $4.5 \%$ for the lower limbs [12, 24].

Poststroke studies frequently involve several problems. Firstly, authors have used different techniques to measure bone density, such as dual-energy X-ray absorptiometry (DXA), computer X-ray densitometry (CXD) and peripheral quantitative computed tomography. Additionally, authors have measured bone density on various sites (e.g. arm, forearm, radius, femur), while BMD measurement at the hip using DXA is considered the standard technique. These problems make generalizability and comparisons troublesome.

While osteoporosis typically affects women more than men, gender has probably a more limited influence in poststroke osteoporosis. Some authors [2, 4, 36, 37] pointed out that women had greater bone loss than men after stroke. However, data were usually obtained by small samples and frequently using techniques and sites of measurement for BMD which are not recommended by current guidelines [38].

A relationship between severity of poststroke osteoporosis and age has not been pointed out in the literature, even if it should be considered that osteoporosis typically affects subjects aged $>65$ years. Therefore, risk assessment in stroke patients should also consider age as an independent factor.

\section{Stroke and Fractures}

Stroke patients are at higher risk than the age- and sexmatched population for fractures [39].

Ramnemark et al. [8] followed a group of 1,139 patients (630 males) admitted consecutively with acute stroke for a median of 2.9 years (4,132 patient-years), reporting 154 fractures in 120 subjects. This equals a poststroke fracture incidence rate of $37 / 1,000$ person-years. $84 \%$ of fractures were caused by falls, and hip fracture was the most common. Hip fracture was 2-4 times more likely than in an age-matched reference population.

Subsequently, Ramnemark et al. [9] examined outcomes in patients with hip fracture and previous stroke. Results showed that survival and recovery of independent mobility after hip fracture were significantly reduced compared with those who had not had a previous stroke.

More recently, Kanis et al. [40] identified 273,288 patients with stroke from a Swedish National Register. They were followed for subsequent hospitalizations for a mean of 2.54 years, observing 24,666 fractures. Of these, 14,263 (58\%) were hip fractures. The authors concluded that, after stroke, patients had a $>7$-fold increase in fracture risk, mainly at the hip. Fracture risk was higher in the younger age groups and during the first year after stroke.

Stroke patients are at high risk for hip fracture because of osteoporosis and falls. Stroke survivors are indeed prone to frequent falls because of reduced strength, balance, visual problems and epilepsy [41, 42]. Forster and Young [43] found that $73 \%$ of stroke patients with mild to moderate disability had fallen in the 6 months after discharge, with falls usually occurring to the side of the paresis [44].

\section{Osteoporosis and Stroke: Physiopathology}

The key mechanism in poststroke osteoporosis is still not well understood. Some etiological factors have been deduced from observational studies, either in stroke patients or in subjects affected by other central nervous system pathologies.

Summarizing, it is possible to describe 4 factors: (1) paresis, reduced mobility and bone load reduction; (2) endocrine factors; (3) nutritional factors, and (4) pharmacological factors.

\section{Paresis, Reduced Mobility and Bone Load Reduction}

In hemiplegic subjects, reduced mobility seems to be the main determinant of bone loss, and length of immobilization is probably an additional factor [2].

The exact physiopathology of immobilization-induced osteopenia is not clearly understood. In patients with spinal cord injury, an increased number of remodeling loci has been observed, leading to increased osteoclastic activity and suppression of osteoblastic stimulus [45]. Increased bone resorption can lead to a phenomenon known as immobilization hypercalcemia.

Generally, immobilization-induced hypercalcemia occurs in situations in which bone turnover is high, such as in children or adolescents with acute neurological diseases like spinal cord injuries, and implies a markedly increased serum calcium concentration as measured by routine assays including both ionized and nonionized calcium. The immobilization-induced hypercalcemia in stroke patients significantly differs from hypercalcemia due to immobilization by other causes [46]. In stroke survivors, who are often elderly, hypercalcemia is milder and usually requires measurement of ionized calcium for its detection. A close correlation has been demonstrated between the degree of immobilization and serum ionized calcium concentration in the first year after stroke and subsequently [20, 22, 47, 48]. 
The correlation between serum calcium measurements and the Barthel Index, pointed out in some studies $[20,22,47]$, implies that the increased calcemia results from bone resorption during immobilization.

Other relationships have been reported between degree of paresis, reduced mobility and osteoporosis, either of the upper or lower extremities [14, 24, 30, 49].

An indirect demonstration of the same phenomenon comes from the observation that patients who can walk more (more steps/day) and who have a higher vertical ground reaction force can maintain a higher BMD [1].

In stroke patients, bone loss is severer in the upper extremities rather than in the lower ones probably because the degree of paresis and loss of function is usually more important in the upper limbs.

Duration of paresis seems to be an important factor in determining the severity of bone loss [2, 18], playing a more important role in the upper rather than lower extremities [3].

Prince et al. [16] found that absence of spasticity, associated with a good functional level, was protective against distal trabecular bone loss. However, since a possible correlation between severe spasticity and low functional level may exist, a relevant bias cannot be completely excluded.

Other studies did not find any relationship between spasticity and bone loss $[5,25,50]$, except for a correlation between spastic hypertonia and osteoporosis of the upper extremities [49].

On the other hand, the relationship between the site of the lesion and osteoporosis in stroke patients has not been studied yet, even if we may argue that a lesion involving the total anterior circulation may lead to severer osteoporosis, due to the more frequent loss of mobility [51].

\section{Endocrine Factors}

Alterations of the vitamin-D-parathyroid-hormone (PTH) axis probably play a relevant role in poststroke osteoporosis.

In the elderly population, who run a higher risk of developing stroke, vitamin $\mathrm{D}$ deficit is dramatically widespread [52]. Some authors showed that up to $83 \%$ of rehabilitative inpatients were vitamin $\mathrm{D}$ deficient [53]. A recent paper showed that osteoporosis and vertebral fractures are frequently preexistent in stroke patients [54]. In this work, authors found a $43.8 \%$ prevalence of osteoporosis in stroke survivors in the acute phase after stroke; their results should anyway be considered with caution, since inclusion and exclusion criteria are unclear and the sample, which is small, is composed by Asians only, who have a higher risk of developing osteoporosis.

Moreover, stroke survivors frequently have impaired mobility, especially outdoors, leading to reduced sunlight exposure and a subsequent vitamin $\mathrm{D}$ deficit $[22,48,55$, 56].

Sunlight exposure up to $15 \mathrm{~min} /$ day can improve plasmatic vitamin D levels and reduce the hip fracture risk in elderly community-living stroke survivors [57].

A possible factor determining poststroke osteoporosis is the inhibition of PTH secretion after stroke.

As previously stated, stroke patients are frequently vitamin D deficient [56]. In vitamin D deficiency, one of the compensatory mechanisms is secondary hyperparathyroidism.

After stroke, mobilization of bone calcium starts rapidly. The exact physiopathological mechanism of this phenomenon is not well understood, even if it is thought to be dependent on immobilization.

Calcium mobilization leads to slightly elevated calcium plasmatic levels, which can be evaluated by measurement of the ionized component for its detection. Hypercalcemia strongly reduces PTH secretion [47], leading to the inhibition of the renal synthesis of 1,25-hydroxyvitamin $\mathrm{D}\left[1,25-(\mathrm{OH})_{2} \mathrm{D}_{3}\right]$. In addition to the inhibition of $1,25-(\mathrm{OH})_{2} \mathrm{D}_{3}$ synthesis, hypercalcemia blocks compensatory hyperparathyroidism, rendering the effect of vitamin D deficiency more evident $[47,48,58]$. Consequently, stroke patients frequently show low plasmatic levels of $25-\mathrm{OHD}_{3}$ and $1,25-(\mathrm{OH})_{2} \mathrm{D}_{3}$, associated with normal or low levels of PTH [47].

Another factor that can be implied in poststroke osteoporosis is vitamin $\mathrm{K}$ deficiency.

Vitamin $\mathrm{K}$ is essential for Gla protein carboxylation, which is indispensable to set up bone matrix $[59,60]$. Reduced circulating Gla protein levels are associated with an elevated hip fracture risk [61]. This observation has also been made in hemiplegic subjects, in whom vitamin $\mathrm{K}$ deficiency, especially vitamin $K_{1}$, is associated with a low BMD and increased hip fracture risk on the paretic side [62].

\section{Nutritional Factors}

Stroke patients are at high risk for poor nutrition due to various mechanisms, such as age, mobility impairment, dysphagia, cognitive deficits and social isolation.

Malnutrition can lead to reduced vitamin D and $\mathrm{K}$ supply, with the previously mentioned possible consequences on bone formation. 
In addition, malnutrition frequently leads to vitamin $\mathrm{B}_{12}$ and folate deficiency. In stroke patients, reduced levels of these two vitamins are common and are associated with secondary hyperhomocysteinemia.

Elevated serum homocysteine is associated with an elevated fracture risk, even if not directly correlated with BMD [63]. The elevated fracture risk in this case may be due to altered bone matrix formation, secondary to hyperhomocysteinemia [63], and not because of a direct reduction of bone mineral content. Therefore, BMD may not be significantly reduced.

In chronic elderly stroke patients, mecobalamin and folate supplementation for 2 years was able to reduce the hip fracture risk [64].

\section{Iatrogenic Factors}

In stroke patients the use of oral anticoagulants is becoming more frequent.

Sato et al. [65] found that hemiplegic stroke patients treated with warfarin had greater BMD reduction compared with hemiplegic patients who did not take anticoagulants. In these patients, bone loss was probably caused by vitamin $\mathrm{K}_{1}$ deficiency and consequently reduced serum Gla protein, secondary to warfarin treatment.

Even in patients without stroke treated with warfarin for nonrheumatic atrial fibrillation, the risk of osteoporotic fractures is higher than in an age-matched population $[66,67]$.

In stroke patients, another possible cause of bone loss is the administration of antiepileptic drugs (AEDs). There is some evidence that AEDs are associated with altered bone and vitamin D metabolism $[68,69]$, either in males [68] or females [70]. Almost all AEDs can produce osteopenia, even because patients are frequently treated with polytherapy [68].

Several mechanisms have been proposed to explain bone disease associated with the use of different AEDs. Induction of the cytochrome P-450 system, resulting in increased vitamin D catabolism, is the most accepted hypothesis $[68,71]$ and is associated with the use of phenobarbital, phenytoin and carbamazepine.

Among AEDs enzyme inductors such as phenytoin, phenobarbital, carbamazepine and primidone can cause greater bone loss compared to noninductors such as clonazepam, topiramate, valproic acid, ethosuximide and gabapentin [69].

Heparin is another drug commonly administered after stroke, which can cause osteoporosis. Heparin is essential in deep-vein thrombosis prophylaxis after stroke, and its use is recommended in recent stroke care guidelines [72]. Even if treatment duration is still debated, deep-vein thrombosis prophylaxis with heparin is frequently performed for 3 months and longer.

A known complication of heparin treatment is osteoporosis. In stroke patients the effect of prolonged heparin treatment has not been specifically addressed, but some data are available in pregnant women treated with heparin for deep-vein thrombosis prophylaxis [73]. Pregnant women treated with unfractionated heparin for 3-6 months can show a reduction of BMD at the femur from 5 to $10 \%[74,75]$, associated with an increased incidence of vertebral fractures $[76,77]$. The use of low-molecularweight heparins has significantly reduced, even if probably not eliminated, this problem $[77,78]$.

Thiazolidine diones, a class of oral antidiabetic drugs approved for type II diabetes mellitus, can have a negative effect on bone mass. Rosiglitazone and pioglitazone seem to increase the risk of fractures in women [79], while rosiglitazone can reduce bone mass in men [80]. This side effect on bone metabolism should be taken into account while considering the overall risk-benefit ratio of antidiabetic therapy in stroke patients.

\section{Poststroke Osteoporosis: Management and Treatment}

Osteoporosis after stroke can be produced by a complex interaction of factors that should be assessed and, if possible, treated.

Possible treatments are: (1) behavioral/rehabilitative treatments; (2) dietary supplementation, and (3) drugs (table 2).

\section{Behavioral/Rehabilitative Treatments}

Since gait deficit and immobility are the main risk factors for developing poststroke osteoporosis, strategies aiming to improve these problems are essential.

Strategies that improve walking capacity and interaction between lower extremities and ground should be used also to limit bone loss [1].

Treatments should be addressed to maximize motor function and strength and to correct deformities that may limit ambulation and, probably, the control of spasticity. Aerobic reconditioning and weight-bearing exercises can improve bone mass in chronic stroke patients [81] and should be emphasized.

Another nonpharmacological strategy is sunlight exposure. Stroke patients frequently suffer from social iso- 
Table 2. Poststroke osteoporosis treatments

\begin{tabular}{|c|c|c|c|c|c|c|}
\hline Authors & Type & Subjects & Treatment & $\begin{array}{l}\text { Treatment } \\
\text { duration }\end{array}$ & $\begin{array}{l}\text { Time from stroke onset } \\
\text { to treatment }\end{array}$ & Results \\
\hline $\begin{array}{l}\text { Sato } \\
\text { et al. [82] }\end{array}$ & $\begin{array}{l}\text { DB PC } \\
\text { RCT }\end{array}$ & $\begin{array}{l}29 \text { women, } \\
25 \text { men }\end{array}$ & $\begin{array}{l}1 \alpha-\mathrm{OHD}_{3}+300 \mathrm{mg} \\
\text { calcium vs. placebo }\end{array}$ & 6 months & $\begin{array}{l}1,822 \pm 2,155 \text { days treatment group, } \\
1,542 \pm 1,628 \text { days placebo group }\end{array}$ & $\begin{array}{l}\text { Vitamin D group had less BMD } \\
\text { reduction and fewer hip fractures }\end{array}$ \\
\hline $\begin{array}{l}\text { Sato } \\
\text { et al. [86] }\end{array}$ & $\begin{array}{l}\text { DB PC } \\
\text { RCT }\end{array}$ & 280 men & $\begin{array}{l}\text { Risedronate } 2.5 \mathrm{mg} / \text { day } \\
\text { vs. placebo }\end{array}$ & 18 months & $\begin{array}{l}90 \pm 0.7 \text { days treatment group, } \\
90 \pm 0.5 \text { days placebo group }\end{array}$ & $\begin{array}{l}\text { Risedronate group showed fewer } \\
\text { hip fractures and less BMD } \\
\text { reduction }\end{array}$ \\
\hline $\begin{array}{l}\text { Sato } \\
\text { et al. [85] }\end{array}$ & $\begin{array}{l}\text { DB PC } \\
\text { RCT }\end{array}$ & 374 women & $\begin{array}{l}\text { Risedronate } 2.5 \mathrm{mg} / \text { day } \\
\text { vs. placebo }\end{array}$ & 12 months & 3 days treatment and placebo group & $\begin{array}{l}\text { Risedronate group showed fewer } \\
\text { hip fractures and less BMD } \\
\text { reduction }\end{array}$ \\
\hline $\begin{array}{l}\text { Sato } \\
\text { et al. [64] }\end{array}$ & $\begin{array}{l}\text { DB PC } \\
\text { RCT }\end{array}$ & $\begin{array}{l}338 \text { women, } \\
290 \text { men }\end{array}$ & $\begin{array}{l}\text { Mecobalamin } 1,500 \mu g+ \\
\text { folate } 5 \mathrm{mg} / \text { day vs. placebo }\end{array}$ & 1 year & $\begin{array}{l}16.9 \pm 4.4 \text { months treatment group, } \\
16.9 \pm 3.6 \text { months placebo group }\end{array}$ & $\begin{array}{l}\text { Mecobalamin and folate reduced } \\
\text { hip fracture risk }\end{array}$ \\
\hline $\begin{array}{l}\text { Sato } \\
\text { et al. [84] }\end{array}$ & $\begin{array}{l}\text { DB PC } \\
\text { RCT }\end{array}$ & $\begin{array}{l}55 \text { men, } \\
53 \text { women }\end{array}$ & $\begin{array}{l}\text { Etidronate } 400 \mathrm{mg} / \mathrm{day} \\
\text { vs. placebo }\end{array}$ & 56 weeks & $\begin{array}{l}7 \pm 0 \text { days in treatment and } \\
\text { placebo groups }\end{array}$ & $\begin{array}{l}\text { Less BMD reduction in } \\
\text { etidronate group }\end{array}$ \\
\hline $\begin{array}{l}\text { Sato } \\
\text { et al. [83] }\end{array}$ & $\begin{array}{l}\text { DB PC } \\
\text { RCT }\end{array}$ & $\begin{array}{l}48 \text { men, } \\
60 \text { women }\end{array}$ & $\begin{array}{l}\text { Menatetrenone } 45 \mathrm{mg} / \text { day } \\
\text { vs. placebo }\end{array}$ & 12 months & $\begin{array}{l}13.2 \pm 7.8 \text { months treatment group, } \\
13.9 \pm 6.4 \text { months placebo group }\end{array}$ & $\begin{array}{l}\text { BMD increased in } \\
\text { menatetrenone group }\end{array}$ \\
\hline $\begin{array}{l}\text { Ikai } \\
\text { et al. [32] }\end{array}$ & $\begin{array}{l}\text { DB PC } \\
\text { RCT }\end{array}$ & 81 women & $\begin{array}{l}\text { Etidronate } 400 \mathrm{mg} / \text { day vs. } \\
200 \mathrm{mg} / \text { day vs. no treatment }\end{array}$ & 3 months & $\begin{array}{l}2.7 \pm 1.4 \text { months treatment group, } \\
2.6 \pm 1.2 \text { months no-treatment group }\end{array}$ & $\begin{array}{l}\text { Etidronate decreased BMD, } \\
\text { reduction in high-ADL subgroup }\end{array}$ \\
\hline $\begin{array}{l}\text { Poole } \\
\text { et al. [87] }\end{array}$ & $\begin{array}{l}\text { DB PC } \\
\text { RCT }\end{array}$ & $\begin{array}{l}21 \text { men, } \\
6 \text { women }\end{array}$ & $\begin{array}{l}\text { Zoledronate } 4 \mathrm{mg} / \text { year } \\
\text { vs. placebo }\end{array}$ & 1 year & $<35$ days & $\begin{array}{l}\text { Zoledronate prevented BMD } \\
\text { reduction }\end{array}$ \\
\hline $\begin{array}{l}\text { Sato } \\
\text { et al. [57] }\end{array}$ & RCT & $\begin{array}{l}52 \text { men, } \\
156 \text { women }\end{array}$ & $\begin{array}{l}\text { Sunlight exposure } 15 \mathrm{~min} / \text { day, } \\
\text { addition vs. no addition }\end{array}$ & 1 year & $\begin{array}{l}3.9 \pm 2.7 \text { years exposed } \\
4.0 \pm 2.0 \text { years deprived }\end{array}$ & $\begin{array}{l}\text { BMD and vitamin D increased in } \\
\text { sunlight-exposed group }\end{array}$ \\
\hline $\begin{array}{l}\text { Uebelhart } \\
\text { et al. [88] }\end{array}$ & $\begin{array}{l}\text { DB PC } \\
\text { RCT }\end{array}$ & $\begin{array}{l}13 \text { women, } \\
21 \text { men }\end{array}$ & $\begin{array}{l}\text { Calcitonin } 200 \mathrm{IU} / \text { day } \\
\text { vs. placebo }\end{array}$ & 2 years & $\begin{array}{l}23 \pm 11 \text { days treatment group, } \\
22 \pm 8 \text { days placebo group }\end{array}$ & $\begin{array}{l}\text { Calcitonin did not influence } \\
\text { bone metabolism markers }\end{array}$ \\
\hline
\end{tabular}
ing.

$\mathrm{DB}=$ Double-blind; $\mathrm{PC}=$ placebo-controlled; $\mathrm{RCT}=$ randomized-controlled trial; $1 \alpha-\mathrm{OHD}_{3}=1 \alpha$-hydroxyvitamin $\mathrm{D}_{3} ; \mathrm{ADL}=$ activities of daily liv-

lation that directly leads to reduced direct sunlight exposure. This is one of the causal factors leading to vitamin D deficiency in stroke survivors [56].

Sato et al. [57] showed that sunlight exposure of the face and hands, for $15 \mathrm{~min} /$ day, can improve $25-\mathrm{OHD}_{3}$ levels and BMD, and reduce hip fracture risk.

\section{Dietary Supplementation}

Since vitamin D deficiency is frequent in stroke patients [56], it seems straightforward to prescribe a supplementation.

In a group of 64 chronic stroke patients [82], daily supplementation with $1 \alpha-\mathrm{OH}$ vitamin $\mathrm{D}$ reduced bone loss and fracture risk. However, the authors provided no details about randomization and the total number of patients evaluated and excluded from the study.

In a randomized controlled trial, ipriflavone (7-isopropoxy-isoflavone) supplementation improved bone mass more than $1 \alpha-\mathrm{OHD}$, in a group of chronic stroke patients [62]. In this paper, details about randomization are lacking, and the effect on BMD reduction was measured at the hand with the CXD technique.

In 628 chronic stroke patients, folic acid and mecobalamin supplementation improved BMD (measured with CXD at the second metacarpal bone) and reduced hip fracture risk, compared to placebo [64].

Also dietary supplementation with $45 \mathrm{mg}$ /day of vitamin $\mathrm{K}_{2}$ (menatetrenone) improved BMD in a group of chronic stroke patients [83]. In this study, however, vita$\min \mathrm{K}_{2}$ was compared to no treatment and not to placebo. Unfortunately, dietary supplementation with vitamin $\mathrm{K}$ analogs is not feasible in patients treated with oral anticoagulants.

\section{Drug Treatment}

Since bone loss starts rapidly after stroke, most studies about drug treatments have been focused on preventing bone loss in hemiplegia, rather than on increasing bone mass in patients who have already developed osteoporosis. 
To prevent poststroke osteoporosis, the first bisphosphonate that has been evaluated was etidronate. A randomized controlled trial performed on 98 stroke patients aged more than 65 years showed that patients who were treated cyclically for a year with etidronate $400 \mathrm{mg} / \mathrm{day}$, started 7 days after stroke, had less BMD reduction compared to the placebo group [84]. Authors evaluated BMD modifications using the CXD technique at the second metacarpal bone, without measurements at the hip.

Another randomized controlled trial compared 40 postmenopausal stroke survivors, treated with etidronate 200 or $400 \mathrm{mg} /$ day for 2 weeks, with 41 age-matched stroke women, not receiving placebo [32]. Treatment was started within 6 months from stroke onset. In this study, etidronate groups showed less BMD reduction compared with the nontreated group. However, in this work, only the more disabled subgroup experienced the larger effect. Moreover this work was not placebo controlled, and details regarding randomization are lacking.

The first drug that not only limited BMD reduction, but also cut down the hip fracture risk after stroke was risedronate. Sato et al. [85] published a double-blind trial in which 374 elderly (aged 65 years or more) stroke women were randomized to receive placebo or $2.5 \mathrm{mg} /$ day risedronate. Both groups received daily supplementation with calcium and vitamin D. Risedronate started within 2 days from stroke onset and administered for a year reduced not only bone loss, but also significantly reduced hip fracture risk.

The same authors performed an analogous study with the same modalities, but on male elderly stroke patients [86]. Also in males $2.5 \mathrm{~g}$ /day risedronate significantly reduced bone loss and the risk of hip fractures.

Major flaws of these studies are that both were performed on Asians only and using doses lower than recommended. Moreover, the authors performed BMD measurements using the CXD technique at the hand.

Recently, Poole et al. [87] published a work performed on 27 hemiplegic stroke patients randomized to receive an early (mean $14 \pm 8$ days after stroke) treatment with a single infusion of $4 \mathrm{mg}$ intravenous zoledronic acid or placebo. Both groups received vitamin D supplementation. Patients treated with zoledronate preserved BMD at the 1-year follow-up, while that in the placebo group decreased. This study was not designed to evaluate the reduction of hip fracture risk.

Another drug that has been evaluated to prevent poststroke osteoporosis is salmon calcitonin. In a doubleblind, randomized, placebo-controlled trial, Uebelhart et al. [88] tested the effect of 200 IU/day salmon calcitonin nasal spray on 34 patients, started within the first month after stroke, administered for 2 years. They found no difference in biochemical markers of bone and connective tissue metabolism reduction between the two groups. This study was not designed to assess BMD or hip fracture risk modifications.

\section{Conclusions}

In comparison to postmenopausal osteoporosis, poststroke osteoporosis is currently not adequately recognized and treated [89]. Inadequate attention has also been paid by researchers, considering the relevance and consequences of this issue. Guidelines for osteoporosis diagnosis and management do not include poststroke osteoporosis.

Management of poststroke osteoporosis should start with a careful and comprehensive risk assessment. The presence of a residual walking deficit should be considered a key factor in the osteoporosis risk assessment for lower limbs.

Then, the known risk factors for osteoporosis in the general population [38] should be evaluated.

For patients with a persistent walking deficit, a BMD assessment at the paretic hip with DXA should always be performed after stroke to assess baseline values.

Therefore, after having considered other risk factors, clinicians should start an antiresorptive treatment, using bisphosphonates, vitamin $\mathrm{D}$ supplementation and ensuring an adequate calcium intake. Vitamin $\mathrm{B}_{12}$ and folate supplementation seems to be safe and effective in preventing hip fractures in chronic stroke survivors and should be recommended.

At the present time, risedronate is the only drug that has been shown to prevent not only bone loss, but also to reduce hip fracture risk in stroke patients $[85,86]$.

Since the first year after stroke is a crucial time for the development of osteoporosis, treatments that inhibit osteoclastic activity, such as bisphosphonates, should be started early.

In patients with chronic stroke and those who have already developed osteoporosis, there is no evidence to support the use of a bisphosphonate instead of another to prevent fractures, among those recommended by current guidelines (alendronate, risedronate, ibandronate, zoledronate) [38].

The available studies suggest that the use of $1 \alpha-\mathrm{OHD}$ could prevent fractures in chronic stroke patients [82] and etidronate could reduce bone loss [32]. Nevertheless, 
at present, etidronate is not recommended for the treatment of postmenopausal and age-related osteoporosis. Moreover, in patients with chronic stroke, other bisphosphonates have not been tested.

It is evident that osteoporosis after stroke needs additional studies in several areas.

The first is the use of more powerful, long-acting and parenterally administered drugs (as ibandronic and zoledronic acid). This could overcome limitations in patients with swallowing disorders and poor compliance.
Studies should be focused on reduction of fractures and prevention of bone loss measured at the hip with DXA.

The second area is the long-term time course of bone loss after stroke. The longest-duration studies have monitored bone loss for 12 months after stroke. Longitudinal studies that continue for more than 2 or 3 years would provide useful information about long-term changes in bone mass and would help the decision to carry on treatment or not.

\section{References}

1 Worthen LC, Kim CM, Kautz SA, Lew HL, Kiratli BJ, Beaupre GS: Key characteristics of walking correlate with bone density in individuals with chronic stroke. J Rehabil Res Dev 2005;42:761-768.

-2 del Puente A, Pappone N, Mandes MG, Mantova D, Scarpa R, Oriente P: Determinants of bone mineral density in immobilization: a study on hemiplegic patients. Osteoporos Int 1996;6:50-54.

3 Hamdy RC, Moore SW, Cancellaro VA, Harvill LM: Long-term effects of strokes on bone mass. Am J Phys Med Rehabil 1995;74:351356.

4 Levendoglu F, Ugurlu H, Gürbilek M, Akkurt E, Karagözoglu E: Increased bone resorption in the proximal femur in patients with hemiplegia. Am J Phys Med Rehabil 2004;83:835-841.

5 Pang MY, Eng JJ, McKay HA, Dawson AS: Reduced hip bone mineral density is related to physical fitness and leg lean mass in ambulatory individuals with chronic stroke. Osteoporos Int 2005;16:1769-1779.

-6 Takamoto S, Masuyama T, Nakajima M, Seikiya K, Kosaka H, Morimoto S, et al: Alterations of bone mineral density of the femurs in hemiplegia. Calcif Tissue Int 1995;56:259_262.

7 Dennis MS, Lo KM, McDowall M, West T: Fractures after stroke: frequency, types, and associations. Stroke 2002;33:728-734.

-8 Ramnemark A, Nyberg L, Borssen B, Olsson T, Gustafson Y: Fractures after stroke. Osteoporos Int 1998;8:92-95.

-9 Ramnemark A, Nilsson M, Borssen B, Gustafson Y: Stroke, a major and increasing risk factor for femoral neck fracture. Stroke 2000; 31:1572-1577.

10 Hodkinson HM, Brain AT: Unilateral osteoporosis in longstanding hemiplegia in the elderly. J Am Geriatr Soc 1967;15:59-64.

-11 Wing H, Leavitt LA: Complications of hemiplegia in cerebrovascular disease. South Med J 1961;54:606-609.
12 Hamdy RC, Krishnaswamy G, Cancellaro V, Whalen K, Harvill L: Changes in bone mineral content and density after stroke. Am J Phys Med Rehabil 1993;72:188-191.

13 Jorgensen L, Crabtree NJ, Reeve J, Jacobsen BK: Ambulatory level and asymmetrical weight bearing after stroke affects bone loss in the upper and lower part of the femoral neck differently: bone adaptation after decreased mechanical loading. Bone 2000;27: 701-707.

14 Jorgensen L, Jacobsen BK, Wilsgaard T, Magnus JH: Walking after stroke: does it matter? Changes in bone mineral density within the first 12 months after stroke: a longitudinal study. Osteoporos Int 2000;11: 381-387.

15 Lazoura O, Groumas N, Antoniadou E, Papadaki PJ, Papadimitriou A, Thriskos P, et al: Bone mineral density alterations in upper and lower extremities 12 months after stroke measured by peripheral quantitative computed tomography and DXA. J Clin Densitom 2008;11:511-517.

16 Prince RL, Price RI, Ho S: Forearm bone loss in hemiplegia: a model for the study of immobilization osteoporosis. J Bone Miner Res 1988;3:305-310

17 Ramnemark A, Nyberg L, Lorentzon R, Englund U, Gustafson Y: Progressive hemiosteoporosis on the paretic side and increased bone mineral density in the nonparetic arm the first year after severe stroke. Osteoporos Int 1999;9:269-275.

-18 Sato Y, Maruoka H, Honda Y, Asoh T, Fujimatsu Y, Oizumi K: Development of osteopenia in the hemiplegic finger in patients with stroke. Eur Neurol 1996;36:278-283.

19 Yavuzer G, Ataman S, Suldur N, Atay M: Bone mineral density in patients with stroke. Int J Rehabil Res 2002;25:235-239.

20 Sato Y, Kuno H, Kaji M, Ohshima Y, Asoh T, Oizumi K: Increased bone resorption during the first year after stroke. Stroke 1998;29: 1373-1377.
21 Frotzler A, Berger M, Knecht H, Eser P: Bone steady-state is established at reduced bone strength after spinal cord injury: a longitudinal study using peripheral quantitative computed tomography (pQCT). Bone 2008; 43:549-555.

22 Sato Y, Fujimatsu Y, Kikuyama M, Kaji M, Oizumi K: Influence of immobilization on bone mass and bone metabolism in hemiplegic elderly patients with a long-standing stroke. J Neurol Sci 1998;156:205-210.

23 Kumar V, Kalita J, Gujral RB, et al: A study of bone densitometry in patients with complex regional pain syndrome after stroke. Postgrad Med J 2001;77:519-522.

24 Pang MY, Eng JJ: Muscle strength is a determinant of bone mineral content in the hemiparetic upper extremity: implications for stroke rehabilitation. Bone 2005;37:103111.

25 Sahin L, Ozoran K, Gunduz OH, Ucan H, Yucel M: Bone mineral density in patients with stroke. Am J Phys Med Rehabil 2001;80: 592-596.

26 Sato Y, Asoh T, Kondo I, Satoh K: Vitamin D deficiency and risk of hip fractures among disabled elderly stroke patients. Stroke 2001; 32:1673-1677.

27 Watanabe Y: An assessment of osteoporosis in stroke patients on rehabilitation admission. Int J Rehabil Res 2004;27:163-166.

28 Whitson HE, Pieper CF, Sanders L, Horner $\mathrm{RD}$, Duncan PW, Lyles KW: Adding injury to insult: fracture risk after stroke in veterans. J Am Geriatr Soc 2006;54:1082-1088.

29 Jorgensen L, Jacobsen BK: Changes in muscle mass, fat mass, and bone mineral content in the legs after stroke: a 1 year prospective study. Bone 2001;28:655-659.

30 Jorgensen L, Jacobsen BK: Functional status of the paretic arm affects the loss of bone mineral in the proximal humerus after stroke: a 1-year prospective study. Calcif Tissue Int 2001;68:11-15 
-31 Ramnemark A, Nyberg L, Lorentzon R, Olsson T, Gustafson Y: Hemiosteoporosis after severe stroke, independent of changes in body composition and weight. Stroke 1999; 30:755-760.

-32 Ikai T, Uematsu M, Eun SS, Kimura C, Hasegawa C, Miyano S: Prevention of secondary osteoporosis postmenopause in hemiplegia. Am J Phys Med Rehabil 2001;80: 169-174.

-33 Liu M, Tsuji T, Higuchi Y, Domen K, Tsujiuchi K, Chino N: Osteoporosis in hemiplegic stroke patients as studied with dual-energy X-ray absorptiometry. Arch Phys Med Rehabil 1999;80:1219-1226.

34 Poole KE, Warburton EA, Reeve J: Rapid long-term bone loss following stroke in a man with osteoporosis and atherosclerosis. Osteoporos Int 2005; 16:302-305.

-35 Iversen E, Hassager C, Christiansen C: The effect of hemiplegia on bone mass and soft tissue body composition. Acta Neurol Scand 1989;79:155-159.

\36 Bainbridge NJ, Davie MW, Haddaway MJ: Bone loss after stroke over 52 weeks at os calcis: influence of sex, mobility and relation to bone density at other sites. Age Ageing 2006; 35:127-132.

-37 Iwamoto J, Tsukimura T, Takeda T: Bone mineral density of metatarsus in hemiplegic subjects. Am J Phys Med Rehabil 1999;78: 202-207.

38 National Osteoporosis Foundation (NOF): Clinician's guide to prevention and treatment of osteoporosis. 2008. http://www.nof. org/professionals/NOF_Clinicians_Guide. pdf (accessed February 12, 2009).

-39 Brown DL, Morgenstern LB, Majersik JJ Kleerekoper M, Lisabeth LD: Risk of fractures after stroke. Cerebrovasc Dis 2008;25: 95-99.

40 Kanis J, Oden A, Johnell O: Acute and longterm increase in fracture risk after hospitalization for stroke. Stroke 2001;32:702-706.

-41 Grisso JA, Kelsey JL, Strom BL, Chiu GY, Maislin G, O’Brien LA, et al: Risk factors for falls as a cause of hip fracture in women. $\mathrm{N}$ Engl J Med 1991;324:1326-1331.

42 Jorgensen L, Engstad T, Jacobsen BK: Higher incidence of falls in long-term stroke survivors than in population controls: depressive symptoms predict falls after stroke. Stroke 2002;33:542-547.

43 Forster A, Young J: Incidence and consequences of falls due to stroke: a systematic inquiry. BMJ 1995;311:83-86.

$\checkmark 44$ Chiu KY, Pun WK, Luk KD, Chow SP: A prospective study on hip fractures in patients with previous cerebrovascular accidents. Injury 1992;23:297-299.

45 Minaire P: Immobilization osteoporosis: a review. Clin Rheumatol 1989;8(suppl 2):95103.
46 Stewart AF, Adler M, Byers CM, Segre GV, Broadus AE: Calcium homeostasis in immobilization: an example of resorptive hypercalciuria. N Engl J Med 1982;306:11361140.

47 Sato Y, Oizumi K, Kuno H, Kaji M: Effect of immobilization upon renal synthesis of 1,25dihydroxyvitamin D in disabled elderly stroke patients. Bone 1999;24:271-275.

48 Sato Y, Kuno H, Asoh T, Honda Y, Oizumi K: Effect of immobilization on vitamin D status and bone mass in chronically hospitalized disabled stroke patients. Age Ageing 1999; 28:265-269.

49 Pang MY, Ashe MC, Eng JJ: Muscle weakness, spasticity and disuse contribute to demineralization and geometric changes in the radius following chronic stroke. Osteoporos Int 2007;18:1243-1252.

50 Pang MY, Ashe MC, Eng JJ: Tibial bone geometry in chronic stroke patients: influence of sex, cardiovascular health, and muscle mass. J Bone Miner Res 2008;23:1023-1030.

51 Baer G, Smith M: The recovery of walking ability and subclassification of stroke. Physiother Res Int 2001;6:135-144.

52 Holick MF: Vitamin D deficiency. N Engl J Med 2007;357:266-281

53 Shinchuk LM, Morse L, Huancahuari N Arum S, Chen TC, Holick MF: Vitamin D deficiency and osteoporosis in rehabilitation inpatients. Arch Phys Med Rehabil 2006;87: 904-908.

54 Kim HW, Kang E, Im S, Ko YJ, Im SA, Lee JI: Prevalence of pre-stroke low bone mineral density and vertebral fracture in first stroke patients. Bone 2008;43:183-186.

55 Kuno H: Vitamin D status and nonhemiplegic bone mass in patients following stroke. Kurume Med J 1998;45:257-263.

56 Sato Y, Maruoka H, Oizumi K, Kikuyama M: Vitamin D deficiency and osteopenia in the hemiplegic limbs of stroke patients. Stroke 1996;27:2183-2187.

57 Sato Y, Metoki N, Iwamoto J, Satoh K: Amelioration of osteoporosis and hypovitaminosis D by sunlight exposure in stroke patients. Neurology 2003;61:338-342.

58 Fujimatsu Y: Role of parathyroid gland on bone mass and metabolism in immobilized stroke patients. Kurume Med J 1998;45:265270.

59 Shearer MJ: Vitamin K. Lancet 1995;345: 229-234.

60 Vermeer C, Jie KSG, Knapen MHJ: Role of vitamin $\mathrm{K}$ in bone metabolism. Annu Rev Nutr 1995; 15:1-22.

61 Szulc P, Arlot M, Chapuy MC, Meunier PJ, Delmas PD: Serum undercarboxylated osteocalcin correlates with hip bone mineral density in elderly women. J Bone Miner Res 1994;9:1591-1595.

-62 Sato Y, Kuno H, Kaji M, Saruwatari N, Oizumi K: Effect of ipriflavone on bone in elderly hemiplegic stroke patients with hypovitaminosis D. Am J Phys Med Rehabil 1999;78: 457-463.
63 van Meurs JB, Dhonukshe-Rutten RA, Pluijm SM, van der Klift M, de Jonge R, Lindemans J: Homocysteine levels and the risk of osteoporotic fracture. N Engl J Med 2004; 350:2033-2041.

64 Sato Y, Honda H, Iwamoto J, Kanoko T, Satoh K: Effect of folate and mecobalamin on hip fractures in patients with stroke. JAMA 2005;293:1082-1088.

65 Sato Y, Honda Y, Kunoh H, Oizumi K: Longterm oral anticoagulation reduces bone mass in patients with previous hemispheric infarction and nonrheumatic atrial fibrillation. Stroke 1997;28:2390-2394.

66 Cheng HY: The association of warfarin use with osteoporotic fracture in elderly patients with atrial fibrillation. Arch Intern Med 2006;166:1525, author reply 1525 .

67 Philip WJ, Martin JC, Richardson JM, Reid DM, Webster J, Douglas AS: Decreased axial and peripheral bone density in patients taking long-term warfarin. Q J Med 1995;88: 635-640.

68 Andress DL, Ozuna J, Tirschwell D, Grande L, Johnson M, Jacobson AF, Spain W: Antiepileptic drug-induced bone loss in young male patients who have seizures. Arch Neurol 2002;59:781-786.

69 Farhat G, Yamout B, Mikati MA, Demirjian S, Sawaya R, El-Hajj Fuleihan G: Effect of antiepileptic drugs on bone density in a mbulatory patients. Neurology 2002;58:13481353.

70 Valimaki MJ, Tiihonen M, Laitinen K, Tahtela R, Karkkainen M, Lamberg-Allardt C, et al: Bone mineral density measured by dualenergy X-ray absorptiometry and novel markers of bone formation and resorption in patients on antiepileptic drugs. J Bone Miner Res 1994;9:631-637.

71 Sheth RD, Wesolowski CA, Jacob JC: Effect of carbamazepine and valproate on bone mineral density. J Pediatr 1995;127:256262.

72 Adams HPJ, del Zoppo G, Alberts MJ, Bhatt DL, Brass L, Furlan A, et al: Guidelines for the early management of adults with ischemic stroke: a guideline from the American Heart Association/American Stroke Association Stroke Council, Clinical Cardiology Council, Cardiovascular Radiology and Intervention Council, and the Atherosclerotic Peripheral Vascular Disease and Quality of Care Outcomes in Research Interdisciplinary Working Groups: the American Academy of Neurology affirms the value of this guideline as an educational tool for neurologists. Stroke 2007;38:1655-1711.

73 Casele H, Haney EI, James A, Rosene-Montella K, Carson M: Bone density changes in women who receive thromboprophylaxis in pregnancy. Am J Obstet Gynecol 2006;195: 1109-1113. 
74 Barbour LA, Kick SD, Steiner JF, LoVerde ME, Heddleston LN, Lear JL, et al: A prospective study of heparin-induced osteoporosis in pregnancy using bone densitometry. Am J Obstet Gynecol 1994;170:862-869.

75 Dahlman TC, Sjoberg HE, Ringertz H: Bone mineral density during long-term prophylaxis with heparin in pregnancy. Am J Obstet Gynecol 1994;170:1315-1320.

-76 Dahlman TC: Osteoporotic fractures and the recurrence of thromboembolism during pregnancy and the puerperium in 184 women undergoing thromboprophylaxis with heparin. Am J Obstet Gynecol 1993;168: 1265-1270.

-77 Monreal M, Lafoz E, Olive A, del Rio L, Vedia C: Comparison of subcutaneous unfractionated heparin with a low molecular weight heparin (Fragmin) in patients with venous thromboembolism and contraindications to coumadin. Thromb Haemost 1994;71:7-11.

$\checkmark 78$ Pettila V, Leinonen P, Markkola A, Hiilesmaa V, Kaaja R: Postpartum bone mineral density in women treated for thromboprophylaxis with unfractionated heparin or LMW heparin. Thromb Haemost 2002;87: 182-196.
-79 Kahn SE, Haffner SM, Heise MA, Herman WH, Holman RR, Jones NP, et al: Glycemic durability of rosiglitazone, metformin, or glyburide monotherapy. N Engl J Med 2006; 355:2427-2443.

80 Yaturu S, Bryant B, Jain S: Thiazolidinediones treatment decreases bone mineral density in type 2 diabetic men. Diabetes Care 2007;30:1574-1576.

81 Pang MY, Ashe MC, Eng JJ, McKay HA, Dawson AS: A 19-week exercise program for people with chronic stroke enhances bone geometry at the tibia: a peripheral quantitative computed tomography study. Osteoporos Int 2006;17:1615-1625.

82 Sato Y, Maruoka H, Oizumi K: Amelioration of hemiplegia-associated osteopenia more than 4 years after stroke by 1 alpha-hydroxyvitamin $\mathrm{D}_{3}$ and calcium supplementation. Stroke 1997;28:736-739.

83 Sato Y, Honda Y, Kuno H, Oizumi K: Menatetrenone ameliorates osteopenia in disuseaffected limbs of vitamin D- and K-deficient stroke patients. Bone 1998;23:291-296.
84 Sato Y, Asoh T, Kaji M, Oizumi K: Beneficial effect of intermittent cyclical etidronate therapy in hemiplegic patients following an acute stroke. J Bone Miner Res 2000;15: 2487-2494.

85 Sato Y, Iwamoto J, Kanoko T, Satoh K: Risedronate therapy for prevention of hip fracture after stroke in elderly women. Neurology 2005;64:811-816.

86 Sato Y, Iwamoto J, Kanoko T, Satoh K: Risedronate sodium therapy for prevention of hip fracture in men 65 years or older after stroke. Arch Intern Med 2005;165:17431748 .

$>87$ Poole KE, Loveridge N, Rose CM, Warburton EA, Reeve J: A single infusion of zoledronate prevents bone loss after stroke. Stroke 2007;38:1519-1525.

$>88$ Uebelhart D, Hartmann DJ, Barbezat S, Mermillod B, Chantraine A: Effect of calcitonin on bone and connective tissue metabolism in hemiplegic patients: a two-year prospective study. Clin Rehabil 1999;13: 384-391.

$>89$ Poole KE, Reeve J, Warburton EA: Falls, fractures, and osteoporosis after stroke: time to think about protection? Stroke 2002;33: 1432-1436. 